УДК 577.18:577.23

О. Б. Кучменко, Д. М. Петухов, І. Н. Свстратова, Л. С. Мхітарян, Г. В. Донченко

Інститут біохімії ім. О. В. Палладіна НАН України

ННЦ Інститут кардіології ім. М. Д. Стражеска АМН України

\title{
ЕФЕКТ ПОПЕРЕДНИКІВ І МОДУЛЯТОРІВ БІОСИНТЕЗУ УБІХІНОНУ НА ВМІСТ І ФУНКЦІОНУВАННЯ УБІХІНОНУ ТА ОКСИДАТИВНИЙ СТАТУС У СЕРЦІ ПРИ ВВЕДЕННІ АДРЕНАЛІНУ
}

Застосування комплексів попередників і модуляторів біосинтезу убіхінону за адреналініндукованої ішемії у щурів як профілактичного та терапевтичного засобу приводить до зниження інтенсивності вільнорадикального окислення ліпідів і білків, збільшення СОД-активності та покращення показників активності комплексів ланцюга транспорту електронів у мітохондріях серця. Комплекси ЕПМ і ЕПМД можна розглядати як ефективні антигіпоксичні засоби, що сприяють нормалізації енергетичного обміну в ішемізованому серці.

Е. Б. Кучменко, Д. Н. Петухов, И. Н. Евстратова, Л. С. Мхитарян, Г. В. Донченко

Институт биохимии им. А. В. Палладина НАН Украины ННЦ Институт кардиологии им. М. Д. Стражеска АМН Украинь

\section{ВЛИЯНИЕ ПРЕДШЕСТВЕННИКОВ И МОДУЛЯТОРОВ БИОСИНТЕЗА УБИХИНОНА НА СОДЕРЖАНИЕ И ФУНКЦИОНИРОВАНИЕ УБИХИНОНА И ОКСИДАТИВНЫЙ СТАТУС В СЕРДЦЕ ПРИ ВВЕДЕНИИ АДРЕНАЛИНА}

\begin{abstract}
Использование комплексов предшественников и модуляторов биосинтеза убихинона при адреналин-индуцированной ишемии у крыс в качестве профилактического и терапевтического средства приводит к снижению интенсивности свободнорадикального окисления липидов и белков, увеличению СОД-активности и улучшению показателей активности комплексов цепи транспорта электронов в митохондриях сердца. Комплексы ЕПМ и ЕПМД можно рассматривать как эффективные антигипоксические средства, способствующие нормализации энергетического обмена в ишемизированном сердце.
\end{abstract}

O. B. Kuchmenko, D. M. Petukhov, I. N. Yevstratova, L. S. Mkhitaryan, G. V. Donchenko

O. V. Palladin Institute of Biochemistry NAS Ukraine

M. D. Strazheska NSC Institute of Cardiology AMS Ukraine

\section{EFFECT OF UBIQUINONE BIOSYNTHESIS PRECURSORS AND MODULATORS ON CONTENT AND FUNCTIONING OF UBIQUINONE AND OXIDATIVE STATUS OF HEART UNDER ADRENALINE TREATMENT}

Preventive and/or subsequent application of precursors and modulators complexes of ubiquinone biosynthesis under the adrenaline treatment reduces free-radical lipid and protein peroxidation intensity, but increases superoxide dismutase activity and improves activities of the mitochondrial electron-transport 
chain complexes. EPM and EPMD complexes can be effective anti-hypoxic remedies that promote normalization of the energy metabolism in ischemic heart.

\section{Вступ}

Одна з ключових подій розвитку ішемії - порушення енергетичного обміну, що супроводжується зменшенням інтенсивності тканинного дихання, вмісту в клітинах АТФ і креатинфосфату [2; 19]. Важливий механізм розвитку ішемії - окисний стрес, тобто порушення балансу між функціонуванням про- та антиоксидантних систем у бік переважання перших $[11 ; 15]$. При цьому перекисне окислення ліпідів (ПОЛ) - один із механізмів пошкоджувального впливу дефіциту кисню, яке може активуватися на певних стадіях гіпоксії та ішемії та призводити до пошкодження мембран [2].

За ішемії зменшується вміст одного з важливих компонентів ланцюга транспорту електронів у мітохондріях - убіхінону (коферменту Q, CoQ), який також проявляє антиоксидантні властивості $[2 ; 5]$.

Пошук біологічно активних сполук, які будуть сприяти зростанню енергетичних можливостей i проявляти антиоксидантні властивості - одна із центральних проблем терапії та профілактики багатьох патологічних станів, у першу чергу серцево-судинної системи. На сьогодні не викликає жодних сумнівів ефективність використання препаратів убіхінону як антигіпоксичних і протиішемічних засобів [24]. Але застосування лікарських препаратів, що містять $\mathrm{CoQ}$, має ряд недоліків: призводить до пригнічення ендогенного синтезу CoQ, є економічно невигідним для пацієнтів через їх високу вартість. Таким чином, пошук підходів до активації ендогенного синтезу CoQ $є$ актуальним.

У наших попередніх роботах показано, що при введенні вітаміну $E$ різним видам тварин спостерігається значне прискорення біосинтезу, накопичення та функціонування $\mathrm{CoQ}$ [5]. Один із проміжних продуктів біосинтезу $\mathrm{CoQ}$ - 4-гідроксибензойна кислота (ПОБК) - на рівні з вітаміном $E$ попереджає розвиток м'язевої дистрофії та викликає аналогічні за спрямованістю зміни активності CoQ-залежних ферментних систем мітохондрій [13]. Також встановлено, що метіонін - важливий донор метальних груп при синтезі поліізопреноїдного бічного ланцюга $\mathrm{CoQ}$ [5].

Мета даної роботи - оцінити дію комплексів попередників і модуляторів біосинтезу CoQ на вміст і функціонування убіхінону та оксидативний статус у тканинах серця щурів при введені ним адреналіну.

\section{Матеріал і методи досліджень}

Досліди проведені на білих безпородних щурах-самцях, масою 300-350 г. Щурів утримували на стандартному раціоні віварію. Тваринам вводили внутрішньом'язево 0,5 мл $0,1 \%$ розчину адреналіну гідрохлориду [10]. Комплекси біологічно активних сполук - попередників і модуляторів біосинтезу CoQ (комплекс ЕПМ складається 3 $\alpha$-токоферолацетату, ПОБК і метіоніну; комплекс ЕПМД - $3 \alpha$-токоферолацетату, ПОБК, метіоніну та диметилсульфоксиду) вводили до і після введення адреналіну (відповідно профілактичний і терапевтичний вплив). Кількості введених сполук приведені в патенті [14]. У випадку профілактичного введення комплекси ЕПМ і ЕПМД вводили перорально протягом 7 діб. Після цього тваринам вводили адреналін. На третю добу тварин декапітували та брали органи для досліджень [2; 10]. У випадку терапевтичного введення спочатку тварини отримували адреналін, а потім протягом 15 діб їм уводили комплекси ЕПМ і ЕПМД перорально. Органи на дослідження брали на шіснадцяту добу після введення адреналіну. Контрольні групи в усіх випадках отримували розчинники - оливкову олію та воду $[2 ; 10]$. Тварин декапітували 3 урахуванням 
вимог Міжнародної конвенції щодо гуманного поводження з тваринами. Серця промивали охолодженим $0,9 \%$ розчином $\mathrm{KCl}$. Методом диференціального центрифугування виділяли фракцію мітохондрій [8], про чистоту та повноту виділення яких робили висновок за активністю сукцинатдегідрогенази та даними електронномікроскопічних досліджень. CoQ і вітамін $E$ розділяли за допомогою тонкошарової хроматографії. Вміст CoQ та вітаміну $E$ визначали спектрофотометрично [4]. NQR (NADH-CoQ-оксидоредуктазну) активність визначали спектрофотометрично за ступенем окислення NADH при довжині хвилі 340 нм [18]. SQR (сукцинат-CoQ-оксидоредуктазну) активність визначали спектрофотометрично за ступенем відновлення 2,6-дихлорфеноліндофенолу відновленим CoQ при довжині хвилі 600 нм [25]. Цитохромоксидазну активність визначали спектрофотометрично за ступенем окислення цитохрому $C$ при довжині хвилі 550 нм [3].

Інтенсивність процесів вільнорадикального окислення оцінювали за вмістом диєнових кон'югатів (ДК), продуктів, що реагують із ТБК, і продуктів окислення білків. Вміст ДК визначали спектрофотометрично за появою нового максимуму у спектрі поглинання за довжини хвилі 233 нм [16]. Вміст ТБК-позитивних продуктів визначали за реакцією з 2-тіобарбітуровою кислотою з утворенням триметинового комплексу спектрофотометрично з максимумом поглинання за довжині хвилі 532 нм [17]. Вміст продуктів вільнорадикального окислення білків визначали спектрофотометрично за реакцією взаємодії окислених амінокислотних залишків білків із 2,4-динітрофенілгідразином з утворенням похідних 2,4-динітрофенілгідразона [12]. Каталазну активність визначали спектрофотометрично за здатністю $\mathrm{H}_{2} \mathrm{O}_{2}$ утворювати стійкий забарвлений комплекс із солями молібдену [6]. Супероксиддисмутазну активність (СОД-активність) визначали за зниженням інтенсивності аутоокислення адреналіну на адренохром, вміст якого оцінювали методом [21]. Вміст білку визначали методом Лоурі [23].

Отримані результати опрацьовані методами варіаційної статистики 3 використанням програми MS Excel. Достовірність різниці двох середніх величин оцінювали за $t$-критерієм Стьюдента.

\section{Результати та їх обговорення}

При введенні адреналіну спостерігається зниження вмісту CoQ у тканинах серця в 1,5-2,5 раза порівняно з контролем. Курсове профілактичне та терапевтичне застосування комплексів ЕПМ і ЕПМД приводило до достовірного (відносно тварин, яким уводили тільки адреналін) зростання його вмісту в серці (табл. 1).

Таблицяя 1

Вміст CoQ і вітаміну $E$ в мітохондріях серця тварин при при введенні адреналіну, профілактичному та терапевтичному введенні комплексів попередників і модуляторів біосинтезу $\mathrm{CoQ},(M \pm m, n=6)$

\begin{tabular}{|l|c|c|c|c|}
\hline \multirow{2}{*}{\multicolumn{1}{|c|}{ Групи }} & \multicolumn{2}{|c|}{ Профілактичне введення } & \multicolumn{2}{c|}{ Терапевтичне введення } \\
\cline { 2 - 5 } & CoQ, мкг/г білку & вітамін $E$, мг/Г білку & CoQ, мкг/Г білку & вітамін $E$, мг/г білку \\
\hline Контроль & $1446,7 \pm 164,9$ & $10,10 \pm 1,15$ & $1139,2 \pm 126,6$ & $6,02 \pm 0,46$ \\
\hline Адреналін & $586,5 \pm 66,9 *$ & $1,90 \pm 0,22 *$ & $748,0 \pm 11,5 *$ & $3,19 \pm 0,18^{*}$ \\
\hline Адреналін + ЕМП & $861,1 \pm 98,2 *$ & $5,99 \pm 0,68 * \#$ & $1181,0 \pm 252,0$ & $7,22 \pm 0,41 \#$ \\
\hline Адреналін + ЕМПД & $745,7 \pm 85,0 *$ & $4,57 \pm 0,52 * \#$ & $1102,8 \pm 33,9 \#$ & $6,60 \pm 0,20 \#$ \\
\hline
\end{tabular}

Примітки: * $-p<0,05$ порівняно $з$ контролем, $\#-p<0,05$ порівняно з групою тварин, яким вводили адреналін.

При адреналін-індукованій ішемії в мітохондріях серця відбувалось достовірне зниження активності комплексів I, II та IV ланцюга транспорту електронів відносно 
контролю. Профілактичне та терапевтичне ведення комплексів ЕПМ і ЕПМД приводило до нормалізації величин цих показників (табл. 2), що вказує на поліпшення роботи дихального ланцюга мітохондрій серця.

Таблиия 2

NADH-CoQ-оксидоредуктазна, сукцинат-CoQ-оксидоредуктазна та цитохромоксидазна активності мітохондрій серця тварин при введенні адреналіну, профілактичному та терапевтичному введенні комплексів попередників і модуляторів біосинтезу $\mathrm{CoQ}(M \pm m, n=6)$

\begin{tabular}{|c|c|c|c|c|c|c|}
\hline \multirow[b]{2}{*}{ Групи } & \multicolumn{3}{|c|}{ Профілактичне введення } & \multicolumn{3}{|c|}{ Терапевтичне введення } \\
\hline & $\begin{array}{c}\text { NQR, млмоль } \\
\text { окисленого } \\
\mathrm{NADH} \cdot \text { хв./мг } \\
\text { білку }\end{array}$ & $\begin{array}{l}\mathrm{SQR}, \text { млмоль } \\
\text { окисленого } \\
\text { сукцинату · } \\
\text { хв./мг білку }\end{array}$ & $\begin{array}{c}\text { цитохром- } \\
\text { оксидазна } \\
\text { активність, } \\
\text { мкмоль окис- } \\
\text { леного цито- } \\
\text { хрому } c \cdot \\
\text { год./мг білку }\end{array}$ & $\begin{array}{l}\text { NQR, млмоль } \\
\text { окисленого } \\
\mathrm{NADH} \cdot \text { хв./мг } \\
\text { білку }\end{array}$ & $\begin{array}{l}\mathrm{SQR}, \text { млмоль } \\
\text { окисленого } \\
\text { сукцинату · } \\
\text { хв./мг білку }\end{array}$ & $\begin{array}{c}\text { цитохром- } \\
\text { оксидазна } \\
\text { активність, } \\
\text { мкмоль окис- } \\
\text { леного цито- } \\
\text { хрому с } \\
\text { год./мг білку }\end{array}$ \\
\hline Контроль & $11,76 \pm 1,39$ & $38,10 \pm 4,53$ & $3,09 \pm 0,17$ & $10,13 \pm 0,31$ & $21,70 \pm 2,11$ & $1,51 \pm 0,17$ \\
\hline Адреналін & $5,48 \pm 0,65 *$ & $23,55 \pm 2,80 *$ & $1,96 \pm 0,23 *$ & $7,17 \pm 0,50 *$ & $14,33 \pm 1,21 *$ & $0,62 \pm 0,07 *$ \\
\hline Адреналін + ЕМП & $18,73 \pm 2,22 * \#$ & $34,18 \pm 4,07$ & $3,90 \pm 0,90$ & $8,33 \pm 0,36^{*}$ & $16,50 \pm 3,39$ & $1,60 \pm 0,18 \#$ \\
\hline Адреналін + ЕМПД & $16,88 \pm 2,01 * \#$ & $41,03 \pm 4,88 \#$ & $2,94 \pm 0,07 \#$ & $8,37 \pm 0,68$ & $21,16 \pm 1,63 \#$ & $1,59 \pm 0,18 \#$ \\
\hline
\end{tabular}

Примітки: див. табл. 1.

Відомо, що один із механізмів порушення функції серця за ішемії - накопичення в цитоплазмі кардіоміоцитів нерозщеплених ацил-СоА з наступним інгібування АТРсинтетичної функції мітохондрій [22]. Цьому процесу сприяє зростаючий за цих умов дефіцит переносників електронів - цитохрому $c$ і убіхінону, пов'язаний із виходом їх із мітохондрій і гальмуванням синтезу убіхінону [9; 20]. Тому позитивні ефекти, отримані при введенні за цих умов комплексів ЕПМ і ЕПМД, можна пояснити зростанням рівня CoQ та його прямим корегувальним впливом на електрон-транспортну функцію дихального ланцюга мітохондрій серця.

Згідно 3 даними літератури адреналове пошкодження серця супроводжується зростанням інтенсивності вільнорадикальних процесів окислення та розвитком окисного стресу $[11 ; 15]$. Зростання рівня ПОЛ може призводити до порушення структури мембран (їх лабілізації та зростання протонної провідності), пригнічення мембранопов'язаних процесів, один з яких - окисне фосфорилювання. Оскільки за ішемії спостерігається дефіцит CoQ, то це може сприяти інтенсифікації ПОЛ і деструкції мембранних структур, у тому числі й мітохондрій. У наших дослідженнях показано, що рівень первинних продуктів окислення ліпідів - ДК у тканинах серця при введенні адреналіну достовірно зростає порівняно 3 контролем в 2,5-5,0 раза (табл. 3). Вміст вторинних продуктів ПОЛ - ТБК-позитивних продуктів - також достовірно зростає в 2,02,5 раза (див. табл. 3). Введення комплексів ЕПМ і ЕПМД приводить до зниження вмісту ДК і ТБК-позитивних продуктів порівняно з тваринами, яким уводили тільки адреналін. Вміст карбонільних продуктів окислення білків - надійний маркер для оцінки стану процесів окислення в клітині. При введенні адреналіну рівень карбонільних продуктів достовірно зростає порівняно 3 контролем в 1,7-2,5 раза (див. табл. 3). Профілактичне та терапевтичне введення комплексів ЕПМ і ЕПМД приводило до достовірного зниження їх вмісту.

Підтримка оптимального редокс-стану клітин потребує адекватного функціонування систем антиоксидантного захисту [11]. Існують дані як про активацію антиоксидантного захисту клітин за умов накопичення продуктів ПОЛ, так і про різке 
незворотне інгібування активності антиоксидантних ферментів $[1 ; 8 ; 11]$. Результати дослідження показали, що при введенні адреналіну відбуваються зміни активності ферментів антиоксидантного захисту. СОД-активність достовірно зменшується (табл. 4). Профілактичне та терапевтичне введення комплексів ЕПМ і ЕПМД призводить до зростання цього показника. При цьому каталазна активність достовірно не змінюється в усіх досліджуваних групах.

Таблиия 3

Вміст продуктів вільнорадикального окислення ліпідів і білків у тканинах серця тварин при введенні адреналіну, профілактичному та терапевтичному введенні комплексів попередників і модуляторів біосинтезу $\operatorname{CoQ}(M \pm m, n=6)$

\begin{tabular}{|l|c|c|c|c|c|c|}
\hline \multirow{2}{*}{ Групи } & \multicolumn{3}{|c|}{ Профілактичне введеня } & \multicolumn{3}{c|}{ Терапевтичне введення } \\
\cline { 2 - 7 } & $\begin{array}{c}\text { диєнові } \\
\text { кон'югати, } \\
\text { ум. од./мг } \\
\text { білку }\end{array}$ & $\begin{array}{c}\text { ТБК-пози- } \\
\text { тивні продук- } \\
\text { ти, ум. од./мг } \\
\text { білку }\end{array}$ & $\begin{array}{c}\text { продукти } \\
\text { окислення } \\
\text { білків, ум. } \\
\text { од./мг білку }\end{array}$ & $\begin{array}{c}\text { диєнові } \\
\text { кон'югати, } \\
\text { ум. од./мг } \\
\text { білку }\end{array}$ & $\begin{array}{c}\text { ТБК-пози- } \\
\text { тивні продук- } \\
\text { ти, ум. од./мг } \\
\text { білку }\end{array}$ & $\begin{array}{c}\text { продукти } \\
\text { окислення } \\
\text { білків, ум. } \\
\text { од./мг білку }\end{array}$ \\
\hline Контроль & $0,12 \pm 0,04$ & $2,91 \pm 1,20$ & $0,58 \pm 0,06$ & $0,11 \pm 0,03$ & $2,63 \pm 0,92$ & $0,91 \pm 0,07$ \\
\hline Адреналін & $0,27 \pm 0,06 *$ & $7,76 \pm 0,33 *$ & $1,51 \pm 0,03 *$ & $0,59 \pm 0,01 *$ & $5,61 \pm 0,85 *$ & $1,54 \pm 0,06 *$ \\
\hline Адреналін + ЕМП & $0,13 \pm 0,01$ & $4,61 \pm 0,40 \#$ & $0,71 \pm 0,04 \#$ & $0,24 \pm 0,06 \#$ & $3,14 \pm 0,13 \#$ & $1,08 \pm 0,26$ \\
\hline Адреналін + ЕМПД & $0,07 \pm 0,01 \#$ & $2,23 \pm 0,22 \#$ & $0,60 \pm 0,05 \#$ & $0,32 \pm 0,01 * \#$ & $3,78 \pm 0,17$ & $0,73 \pm 0,13 \#$ \\
\hline
\end{tabular}

Примітки: див. табл. 1.

Каталазна та супероксиддисмутазна активності у тканинах серця тварин при введенні адреналіну, профілактичному та терапевтичному введенні комплексів попередників і модуляторів біосинтезу $\operatorname{CoQ}(M \pm m, n=6)$

\begin{tabular}{|l|c|c|c|c|}
\hline \multirow{2}{*}{ Групи } & \multicolumn{2}{|c|}{ Профілактичн введення } & \multicolumn{2}{c|}{ Терапевтичне введення } \\
\cline { 2 - 5 } & $\begin{array}{c}\text { каталазна активність, } \\
\text { мкат/г білку · год. }\end{array}$ & $\begin{array}{c}\text { СОД-активність, } \\
\text { од./мг білку хв. }\end{array}$ & $\begin{array}{c}\text { каталазна активність, } \\
\text { мкат/г білку г год. }\end{array}$ & $\begin{array}{c}\text { СОД-активність, } \\
\text { од./мг білку } \cdot \text { хв. }\end{array}$ \\
\hline Контроль & $37,92 \pm 9,31$ & $546 \pm 64$ & $31,76 \pm 5,74$ & $1766 \pm 506$ \\
\hline Адреналін & $26,98 \pm 3,83$ & $323 \pm 9 *$ & $34,67 \pm 3,71$ & $876 \pm 149$ \\
\hline Адреналін + ЕМП & $30,27 \pm 1,29$ & $472 \pm 72$ & $31,97 \pm 0,17$ & $1191 \pm 69$ \\
\hline Адреналін + ЕМПД & $25,24 \pm 3,21$ & $403 \pm 32 \#$ & $30,12 \pm 1,53$ & $1283 \pm 86 \#$ \\
\hline
\end{tabular}

Примітки: див. табл. 1.

Під дією великих доз адреналіну активуються гіпоксичні, кальцієві та вільнорадикальні механізми пошкодження клітин і відповідні захисно-компенсаторні реакції 3 боку клітин (перебудови енергетичного обміну, транспортних систем, що видаляють надлишки $\mathrm{Ca}^{2+}$ із цитоплазми, збільшення активності антиоксидантних систем). Обов'язкова умова ефективної діяльності антиоксидантних систем - їх достатнє енергетичне та пластичне забезпечення, що, у свою чергу, залежить від загального вихідного рівня енергетичного обміну клітини, можливостей максимального та стійкого збільшення його потужності за умов уведення адреналіну.

\section{Висновки}

Застосування комплексів попередників і модуляторів біосинтезу убіхінону за адреналін-індукованої ішемії у щурів як профілактичного та терапевтичного засобу дозволило суттєво знизити інтенсивність вільнорадикального окислення ліпідів і білків, збільшити СОД-активність і покращити показники активності комплексів ланцюга транспорту електронів у мітохондріях серця. Отримані дані свідчать про здатність даних комплексів справляти корегувальну дію на компоненти дихального ланцюга 
мітохондрій серця за умов гіпоксії. Комплекси ЕПМ і ЕПМД, як і препарати екзогенного убіхінону, можна розглядати як ефективні антигіпоксичні засоби, що сприяють нормалізації енергетичного обміну в ішемізованому серці.

\section{Бібліографічні посилання}

1. Барабой В. А. Окислительно-антиоксидантный гомеостаз в норме и патологии / В. А. Барабой, Д. А. Сутковой. - К. : Чернобыль-интеринформ, 1997. - Ч. 2. - 220 с.

2. Влияние убихинона-10 на энергетический обмен и ПОЛ в миокарде крыс при ишемии / В. Н. Крылов, Л. Д. Лукьянова, А. С. Корягин, Е. В. Ястребова // Бюлл. экспер. биол. и мед. 2000. - Т. 130, № 7. - С. 35-38.

3. Гулидова Г. П. Некоторые условия спектрофотометрического определения активности сукцинатдегидрогеназы и цитохромоксидазы в митохондриях мозга / Г. П. Гулидова, И. Н. Сорокина // Бюлл. эксп. биол. и мед. - 1967. - Т. 63, № 1. - С. 41-44.

4. Действие производных токоферола на содержание природных хинонов в тканях витамин $E$ недостаточных крыс / Г. В. Донченко, В. Н. Коваленко, Е. Н. Забарная и др. // Биохимия. 1979. - Т. 44, № 5. - С. 923-930.

5. Донченко Г. В. Биохимия убихинона. - К. : Наук. думка, 1988. - 240 с.

6. Королюк М. А. Метод определения активности каталазы / М. А. Королюк, М. И. Иванова // Лаб. дело. - 1988. - № 1. - С. 16-18.

7. Костерин С. А. Роль сарколеммы и митохондрий в обеспечении кальциевого контроля расслабления миометрия / С. А. Костерин, Н. Ф. Браткова, М. Д. Курский // Биохимия. - 1985. Т. 50, вып. 8. - С. 1350-1361.

8. Ланкин В. 3. Свободнорадикальные процессы при заболеваниях сердечно-сосудистой системы / В. 3. Ланкин, А. К. Тихазе, Ю. Н. Беленков // Кардиология. -2000. - Т. 40, № 7. - С. 48-61.

9. Лукьянова Л. Д. Биоэнергетическая гипоксия: понятие, механизмы и способы коррекции // Бюлл. экспер. биол. и мед. - 1997. - Т. 124, № 9. - С. 244-254.

10. Моделирование заболеваний / Под ред. С. В. Андреева. - М., 1973. - С. 198-223.

11. Мхітарян Л. С. Окислювальний стрес: механізми розвитку і роль в патології / Л. С. Мхітарян, О. Б. Кучменко. - К., 2004. -223 с.

12. Окислительная модификация белков крови человека: метод определения / Е. Е. Дубинина, С. О. Бурмистров, Д. А. Ходов и др. // Вопросы мед. химии. - 1995. - Т. 41, № 1. - С. $24-26$.

13. Патент 73433 Україна 7 А61К31/192, 31/355, А61Р3/00 Спосіб відновлення та активації ендогенних систем біосинтезу та функціонування убіхінону в організмі / Г. В.Донченко, І. В. Кузьменко, Д. М. Петухов, К. П. Кліменко - Заявл. 14.01.2004 р., опубл. 15.07.2005 р. Бюл. № 7.

14. Патент 82639, Україна, А61К31/355 Комплексний препарат для підвищення внутрішньоклітинного енергетичного обміну в організмі / Г. В. Донченко, І. В. Кузьменко, О. Б. Кучменко, Д. М. Петухов. - Заявл. 26.09.2006 р., опубл. 25.04.2008 р. - Бюл. № 8.

15. Свободнорадикальное окисление и старение / В. Х. Хавинсон, В. А. Баринов, А. В. Арутюнян, В. В. Малинин. - СПб : Наука, 2003. - 327 с.

16. Стальная И. Д. Метод определения диеновой конъюгации ненасыщенных жирных кислот // Современные методы в биохимии / Под ред. В. Н. Ореховича. - М. : Медицина, 1977. - С. 63-64.

17. Стальная И. Д. Метод определения малонового диальдегида с помощью тиобарбитуровой кислоты / И. Д. Стальная, Т. Г. Гаришвили // Современные методы в биологии / Под. ред. В. Н. Ореховича. - М., 1977. - С. $44-46$.

18. Hatefi Y. Preparation and properties of DPNH-coenzyme $Q$ reductase (Complex $I$ of the Respiratory Chain) / Y. Hatefi, J. S. Rieske // Methods in Enzymology. - 1967. - Vol. 10. - P. 235-239.

19. Huss J. M. Mitochondrial energy metabolism in heart failure: A question of balance / J. M. Huss, D. P. Kelly // J. Clin. Investig. - 2005. - Vol. 115, N 3. - P. 547-555.

20. Inhibition of ubiquinone synthesis in isolated rat heart under an ischemic condition / H. Sugawara, T. Yamamoto, S. Shimizu, K. Momose // Int. Biochem. - 1990. - Vol. 25, N 5. - P. 477-480. 
21. Misra H. P. Role of superoxide anion in the autooxidation of epinephrine. A simple assay for superoxide dismutase / H. P. Misra, I. Fridovich // J. Biol. Chem. - 1972. - Vol. 247, N 10. P. 3170-3175.

22. Paulson D. J. Inhibition of the adenine nucleotide translocator by matrix-localized palmityl-CoA in rat heart mitochondria / D. J. Paulson, A. L. Shug // Biochem. Biophys. Acta. - 1984. - Vol. 766, N 1. - P. 70-76.

23. Protein measurement the folin phenol reagent / O. H. Lowry, H. J. Rosenbrough, A. L. Parr, R. J. Randall // J. Biol. Chem. - 1951. - Vol. 193, N 1. - P. 265-275.

24. Sarter B. Coenzyme $Q_{10}$ and cardiovascular disease: A review // J. Cardiovasc. Nurs. - 2002. Vol. 16, N 4. - P. 9-20.

25. Ziegler D. Preparation and properties of succinate dehydrogenase-coenzyme $Q$ reductase (complex II) / D. Ziegler, K. A. Doeg // Methods in Enzymology. - 1967. - Vol. 10. - P. 231-235.

Надійшла до редколегії 17.06.2011 